\title{
Local Wisdom of Bonai People in ulak patian, Riau
}

\section{Nilai-nilai kearifan lokal masyarakat suku bonai di ulak patian, Riau}

Ryan Prayogi

Study Program of Social Studies Education, University of Pasir Pengaraian, Indonesia. E-mail: ryanprayogi@upp.ac.id

\begin{tabular}{|c|c|}
\hline ARTICLE INFO & ABSTRACT \\
\hline $\begin{array}{l}\text { Keywords: } \\
\text { Local wisdom; etnography; } \\
\text { Bonai tribe; values; } \\
\text { culture. } \\
\text { How to cite: } \\
\text { Prayogi, } R \text {. (2020). Nilai- } \\
\text { nilai kearifan lokal pada } \\
\text { masyarakat suku bonai di } \\
\text { ulak patina, Riau. } \\
\text { ETNOSIA: Jurnal } \\
\text { Etnografi Indonesia. 5(1): } \\
\text { 50 - 65. }\end{array}$ & $\begin{array}{l}\text { This research aims to describe cultural values as local wisdom of the } \\
\text { Bonai tribe in establishing the identity of a nation, particularly at Ulak } \\
\text { Patian, Riau. This study uses a qualitative approach with } \\
\text { ethnographic methods. Data collection techniques used are } \\
\text { observation, interviews, documentation. The results of research on } \\
\text { cultural values as the local wisdom of the Bonai tribe in Ulak Patian } \\
\text { are carried out by declining ancestral heritage as traditional social } \\
\text { attitudes and behavior. There are many types of local wisdom that are } \\
\text { described in this article, which is a cultural identity possessed by the } \\
\text { Bonai Tribe. This identity has been transformed as a cultural force that } \\
\text { must be maintained until now. The current swift current of } \\
\text { globalization makes all ethnic groups in Indonesia need to be kept their } \\
\text { cultural identity. }\end{array}$ \\
\hline $\begin{array}{l}\text { DOI: } \\
\text { 10.31947/etnosia.v5i1.8953 }\end{array}$ & \\
\hline
\end{tabular}

\section{Pendahuluan}

Indonesia merupakan salah satu bangsa yang kaya keanekaragaman budayanya, hal ini dikarenakan Indonesia terdiri dari berbagai suku bangsa dimana masing-masing suku bangsa tersebut memiliki perbedaan budaya dan keunikan baik dari segi bahasa daerah, adat istiadat, kebiasaan, dan berbagai hal lain yang memperkaya kebudayaan bangsa Indonesia. Dalam UU No. 5 Tahun 2017 tentang pemajuan kebudayaan dalam pasal 1 bahwa kebudayaan adalah segala sesuatu yang berkaitan dengan cipta, rasa, dan karsa dan hasil karya masyarakat. Senada dengan pendapat Soemardjan, S dan Soemardi, S (1964) Kebudayaan merupakan hasil karya, rasa, dan cipta masyarakat. Kebudayaan dapat diartikan sebagai hasil karya, rasa, dan cipta manusia berupa buah pikiran, gagasan, norma, ide, aktivitas manusia untuk memenuhi kebutuhan hidupnya (Ellya, R., 2017). 
Menurut Taylor (Horton \& Chester, 1996) bahwa kebudayaan adalah 'kompleks keseluruhan dari pengetahuan, keyakinan, kesenian, moral, hukum, adat istiadat dan semua kemampuan dan kebiasaan yang lain yang diperoleh oleh seseorang sebagai anggota masyarakat.' Menurut Koentjaraningrat (2009) kebudayaan daerah sama dengan konsep suku bangsa. Suatu kebudayaan tidak terlepas dari pola kegiatan masyarakat. Keragaman budaya daerah bergantung pada faktor geografis. Semakin besar wilayahnya, maka makin kompleks perbedaan kebudayaan satu dengan yang lain. Jika kita melihat dari ujung pulau Sumatera sampai ke pulau Irian tercatat sekitar 300 suku bangsa dengan bahasa, adat-istiadat, dan agama yang berbeda. Koentjaranigrat (2009) juga menyatakan bahwa terdapat tujuh unsur kebudayaan sebagai isi pokok dari tiap kebudayaan di dunia, yaitu: Bahasa, Sistem pengetahuan, Organisasi sosial, Sistem peralatan hidup dan teknologi, Sistem mata pencaharian hidup, Sistem religi, Kesenian. Maka dari itu, setiap unsur kebudayan memiliki sistem nilai, sistem sosial dan karya budaya dalam kehidupan manusia khususnya suku Bonai.

Apriyanto mengatakan kearifan lokal adalah berbagai nilai yang diciptakan, dikembangkan dan dipertahankan oleh masyarakat yang menjadi pedoman hidup mereka. Tradisi memperlihatkan bagaimana anggota masyarakat bertingkah laku, baik dalam kehidupan bersifat duniawi (Alus, C., 2014). Sejalan pendapat Fajarini, U (2014) bahwa menggali dan melestarikan berbagai unsur kearifan lokal, tradisi dan pranata lokal, termasuk norma dan adat istiadat yang bermanfaat, dapat berfungsi secara efektif dalam pendidikan karakter, sambil melakukan kajian dan pengayaan dengan kearifankearifan baru. Oleh sebab itu, perlunya sebuah kemampuan dalam masyarakat suku Bonai untuk melestarikan budaya dan kearifan lokal dalam masyarakat suku Bonai. Pada dasarnya ada pepatah yang mengatakan dikutip dari Anggoro (2010) mengatakan "lebih baik mati anak daripada mati adat." Ungkapan yang sederhana tetapi memiliki sebuah makna yang sangat luas. (Islamuddin, 2014). Peneliti mencoba memaknainya bahwa suku Bonai memiliki kearifan lokal yang menjadi pedoman hidup yang harus ditaati oleh masyarakat suku Bonai di Ulak Patian baik dalam tradisi, adat istiadat, dan norma yang berlaku, serta nilai-nilai budaya tersebut telah diwariskan secara turun temurun oleh masyarakat suku Bonai. Temuan penelitian sebelumnya Prayogi, R \& Danial, E (2016) bahwa prinsip kehidupan yang menjadi suatu pedoman, pegangan, peraturan harus ditaati oleh masyarakat suku Bonai di Kecamatan Bonai Darussalam secara turun temurun meliputi: Kelahiran, Sunat Rosul, Nikah Kawin, Sistem Kepemimpinan Masyarakat, Kematian. Maka, berdasarkan prinsip yang melekat dalam kehidupan masyarakat suku Bonai menjadi suatu pedoman secara turun temurun yang harus dilestarikan sebagai kearifan lokal masyarakat suku Bonai. Sesuai Permen Lingkungan Hidup dan Kehutanan No. P.34 tahun 2017 Pasal 1 bahwa Kearifan Lokal adalah nilai-nilai luhur yang berlaku dalam tata kehidupan masyarakat setempat antara lain untuk melindungi dan mengelola lingkungan hidup dan sumber daya alam secara lestari. Melalui nilai kearifan lokal adalah upaya untuk mempertahakan sebuah budaya dalam suatu bangsa. Begitupun dengan Soebadio mengatakan local genius adalah "cultural identity" identitas budaya bangsa yang menyebabkan bangsa tersebut mampu menyerap dan mengolah kebudayaan asing sesuai watak dan kemampuan sendiri (Ayatrohaedi, 1986). 
Permasalahan dalam penelitian ini bahwa kebudayaan masyarakat suku Bonai di Ulak Patian mengalami kemunduran fungsi kearifan lokal akibat dampak negatif pengaruh globalisasi dan perubahan sosial masyarakat. Sehingga timbul krisis jati diri masyarakat, rendahnya tingkat pendidikan, kesejahteraan, kesadaran masyarakat terhadap upaya pelestarian nilai budaya dan kearifan lokal. Selanjutnya dari segi ritual tradisi pendapat Yance, I (2018) mengatakan bahwa saat ini mayoritas suku Bonai beragama Islam, tetapi tradisi dan kepercayaan berbau animisme masih tetap berlangsung. Ritual - ritual tradisi tersebut akibat persentuhan dengan Islam, mulai mengalami perubahan. Dari segi urgensi, kajian suku Bonai ini perlu untuk dikaji dalam aspek kebudayaan dan kearifan lokal dari konsep budaya kewarganegaraan (civic culture) agar identitas dan jati diri bangsa tetap terjaga dalam melestarikan dan mengembangkan kearifan lokal suku Bonai, serta diatur dalam Pasal 63 ayat (1) huruf t Undang-Undang No. 32 Tahun 2009 "Perlindungan dan Pengelolaan Lingkungan Hidup", dalam melaksanakan implementasi pengakuan hukum adat, kearifan lokal, dan hak masyarakat hukum adat serta sesuai Permen Lingkungan Hidup dan Kehutanan No. P.34 tahun 2017 tentang Pengakuan Dan Perlindungan Kearifan Lokal Dalam Pengelolaan Sumber Daya Alam Dan Lingkungan Hidup. Kajian artikel ini akan menjelaskan tentang Nilai-Nilai Kearifan Lokal Pada Masyarakat Suku Bonai Di Ulak Patian Kecamatan Kepenuhan Kabupaten Rokan Hulu Provinsi Riau.

Artikel ini bertujuan untuk mendeskripsikan nilai-nilai budaya suku Bonai sebagai kearifan lokal dalam budaya suku Bonai yang merupakan sebuah identitas budaya. Nilai-nilai budaya yang masih dijumpai dalam setiap terancam punah akibat dari globalisasi dan perubahan sosial masyarakat yang mengakibatkan kehilangan jati diri, kehilangan identitas, serta kehilangan kearifan lokal di dalam nilai-nilai budaya masyarakat suku Bonai di Desa Ulak Patian.

\section{Metode}

Metode yang digunakan dalam penelitian ini adalah penelitian kualitatif dengan pendekatan etnografi. Bertujuan untuk mendeskripsikan nilai-nilai budaya suku Bonai sebagai kearifan lokal. Penelitian ini dilakukan di Desa Ulak Patian Kecamatan Kepenuhan Kabupaten Rokan Hulu. Dipilih secara sengaja dengan pertimbangan bahwa Suku Bonai merupakan salah satu suku terasing di kawasan Provinsi Riau. Dimana terdapat suku lainnya yaitu suku Sakai, suku Talang Mamak, Kubu, Orang Hutan, dan suku Laut atau suku Akit. Kebudayaan suku Bonai berpendirian terhadap beberapa aspek, diantaranya pengetahuan, keyakinan, seni, moral, hukum, adatistiadat, serta kemampuan-kemampuan dan kebiasaan lainnya yang diperoleh sebagai anggota masyarakat suku Bonai. Teknik pengumpulan data adalah observasi partisipan, wawancara mendalam (indept interview), dokumentasi, dan triangulasi. Observasi partisipan, dilakukan mengamati perilaku, aktivitas masyarakat suku Bonai. Kegiatan yang diobservasi adalah kegiatan mendengarkan dan memahami yang mereka ucapkan, dan berpartipasi dalam aktivitas mereka dilokasi penelitian. Wawancara mendalam (indept interview), dilakukan untuk mendapatkan data-data yang terkait dengan kebiasaan, pengetahuan, keyakinan, seni, moral, hukum, adat-istiadat yang merupakan nilai-nilai budaya suku bonai sebagai kearifan lokal masyarakat. Dokumentasi, dilakukan untuk mendapatkan bukti-bukti terkait dengan nilai-nilai 
budaya dalam setiap aktifitas masyarakat suku Bonai. Teknik analisis data menggunakan teori Miles \& Huberman (2007) bahwa ada terdiri dari tiga alur kegiatan secara bersamaan yaitu "pengumpulan data/reduksi data, display data dan penarikan kesimpulan/verifikasi data". Sebagai pendukung keabsahan data dalam penelitian ini digunakan Teknik Triangulasi, agar peneliti dapat mengetahui data yang diperoleh apakah meluas, tidak konsisten dan kontradiksi.

Daftar nama-nama informan yang peneliti wawancarai selama melakukan penelitian dapat dilihat pada tabel berikut ini: subjek penelitian adalah Datuk Adat, Tokoh Agama, Tokoh Pemuda, Camat Kepenuhan, Dinas Pariwisata dan Kebudayaan, dan Budayawan Rokan Hulu.

Tabel 1. Daftar Nama Informan Penelitian

\begin{tabular}{lllll}
\hline No. & \multicolumn{1}{c}{ Nama } & Usia & \multicolumn{1}{c}{ Pekerjaan } & \multicolumn{1}{c}{ Posisi } \\
\hline 1 & Zainuddin & 38 th & Kepala Desa & Aparat Desa \\
\hline 2 & M. Yunus & 30 th & Sekretaris Desa & Aparat Desa \\
\hline 3 & Khalifah Umar & 90 th & Imam Masjid & Tokoh Masyarakat \\
\hline 4 & Sahril & 55 th & Nelayan & Tokoh Adat \\
\hline 5 & M. Rasyid & 60 th & Pelaku Seni & Pimpinan Tari \\
\hline 6 & Khalifah Wannor & 55 th & Imam Masjid & Tokoh Agama \\
\hline 7 & Amrizal & 38 th & Nelayan & Tokoh Pemuda \\
\hline 8 & M. Midun & 30 th & Perangkat Desa & Masyarakat Desa \\
\hline 9 & Gustia Hendri & 34 th & Camat Kepenuhan & Aparat Pemerintah \\
\hline 10 & Yusmar & 51 th & Kadis Parbud & Aparat Pemerintah \\
\hline
\end{tabular}

\section{Hasil penelitian dan pembahasan}

\section{Deskripsi Nilai-Nilai Budaya Suku Bonai Sebagai Kearifan Lokal}

Suku Bonai di Ulak Patian memiliki nilai-nilai budaya sebagai kearifan lokal yang menjadi prinsip dalam kehidupan masyarakat suku Bonai, nilai - nilai budaya ini menjadi bagian yang tidak dapat dipisahkan dalam interaksi sosial masyarakat merupakan jati diri suku Bonai selama ini meliputi: Tradisi Cukuo Rambuik, Sunat Rosul, Nikah Kawin (Kunduri Bosa) yang memiliki prosesi adat Bucinok-cinok, Muanta kato, Muanta Tando, Poncak Silek, Ijab Kobul, Malam Buinai, Koba (Bukoba), Upah-upah, Gondang Berogong dan Tradisi dalam Tarian Cegak, Buwong Kuayang, dan permainan Lukah Gilo serta Tahan Kulik. Dalam konsep ini berarti, Tradisi masyarakat suku Bonai merupakan kearifan lokal ditandai dengan adanya nilai-nilai budaya yang terkandung dalam masyarakat suku Bonai sebagai warisan nenek moyang yang dilaksanakan secara turun temurun.

\section{- Tradisi cukuo rambuik (cukur rambut)}

Berdasarkan temuan penelitian dilapangan bahwa nilai - nilai budaya suku Bonai sebagai kearifan lokal sudah ada sejak dahulu dalam kehidupan masyarakat suku Bonai seperti upacara Kelahiran cukur rambut (Aqiqah Cukuo Rambuik). Proses upacara cukuo rambuik diperuntukkan pada anak yang berusia kurang dari satu tahun setelah kelahiran atau umumnya dilakukan 7 hari sampai 40 hari, waktu pelaksanaannya pada pagi hari dan siang hari setelah dzuhur sampai selesai. Seperti yang diceritakan oleh Khalifah Wannor mengatakan; 
"Aqiqah cukuo rambuik di kampong ini selalu dilaksanakan ketiko anak yang baru lahir sekitar satu minggu atau sebulan merupakan kewajiban bagi umat islam untuk memberikan nama pada anak tersebut dan mendo'akan supaya kelak menjadi orang berguna dan taat ajaran agama. Tempat pelaksanannya bisa didalam rumah, luar rumah dan dilapangan tergantung orang punya hajat. Sedangkan keluarga yang hadir mempersiapkan perlengkapan buaian tempat anak untuk diayun yang dihiasi dengan pita beraneka warna, sedangkan kain dipilinkan ditempat tali gantungan lalu digelembungkan. Pada prosesi dimulai pembukaan oleh pembawa acara, kedua, pembacaan kalam ilahi oleh orang yang dituakan (Khulifah), kata sambutan tuan rumah, upah - upah, do'a aqiqah, membaca barzanji, marhabban, tepung tawar, naik buai, dan diakhiri makan bersama (makan bukoca)." (Khalifah Wannor, 55 Tahun).

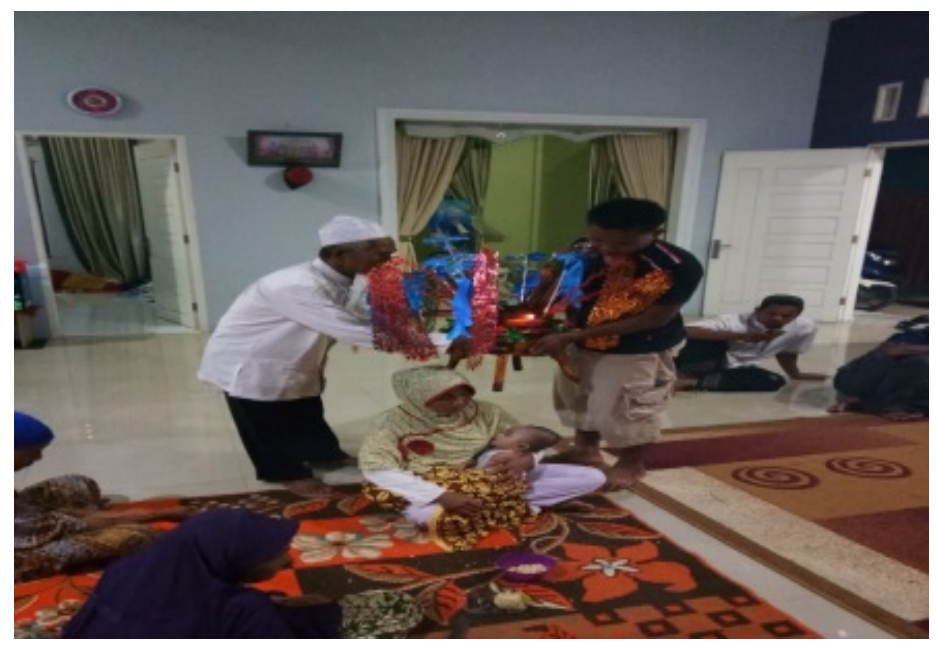

Gambar 1. Tradisi Cukuo Rambuik

Sumber: Dokumen Penelitian, 2019

\section{- Tradisi sunat rosul (khitanan)}

Nilai - nilai budaya suku Bonai sebagai kearifan lokal dapat dilihat pada tradisi Khitanan (sunat rosul). Upacara Sunat Rosul merupakan upacara yang dilaksanakan kepada anak yang berusia dari bayi sampai sepuluh tahun yang sudah dianggap dewasa. Pada proses sunat rosul ini merupakan suatu yang disyariatkan dalam islam serta wajib hukumnya bagi anak laki-laki maupun perempuan. Upacara Sunat Rosul ini dilaksanakan satu hari satu malam sampai tiga hari tiga malam tergantung kesanggupan dari pihak keluarga. Seperti yang diceritakan oleh Khalifah Umar mengatakan;

" tradisi sunat rosul di ulak patina sama dengan di daerah lain pada umumnya tetapi ada perbedaan secara adat yang mana dalam adat suku Bonai dilaksanakan tigo hari tigo malam dengan pembuatan gelanggang (pelaminan adat) dan rapat kerja masyarakat untuk membantu prosesi sunat rosul. Pada hari pertama Biasanya bapak-bapak membuat gelanggang sedangkan ibu-ibu memasak dan melengkapi bahan seperti: beras putih, beras kuning, bertih, dan bunga rampai, panggang ayam untuk pembuatan nasi kunyit bopangkat, hiasan gelanggang, dan pakaian adat bagi anak yang disunat. Hari kedua setelah anak disunat, maka dipakaikan pakaian adat atau baju muslim, kain sarung dan peci oleh orang tuanya. Setelah itu masuk ke prosesi tepung tawar dan upah-upah meletahkan nasi kunyit bopangkat diatas kepala anak dengan sambil membaca do'a 
keselamatan dan kemurahan rezeki secara bergantian, biasanya di mulai dari orang tertua adat lalu sampai ke pihak keluarga. Hari ketiganya dilaksanakan acara hiburan berupa rebana, poncak silek, musik celempong, tarian-tarian (tari cegak dan tari buwong kuayang) dan makan bukoca (makan bersama) sebagai acara penutupnya." (Khalifah Umar, 90 Tahun).

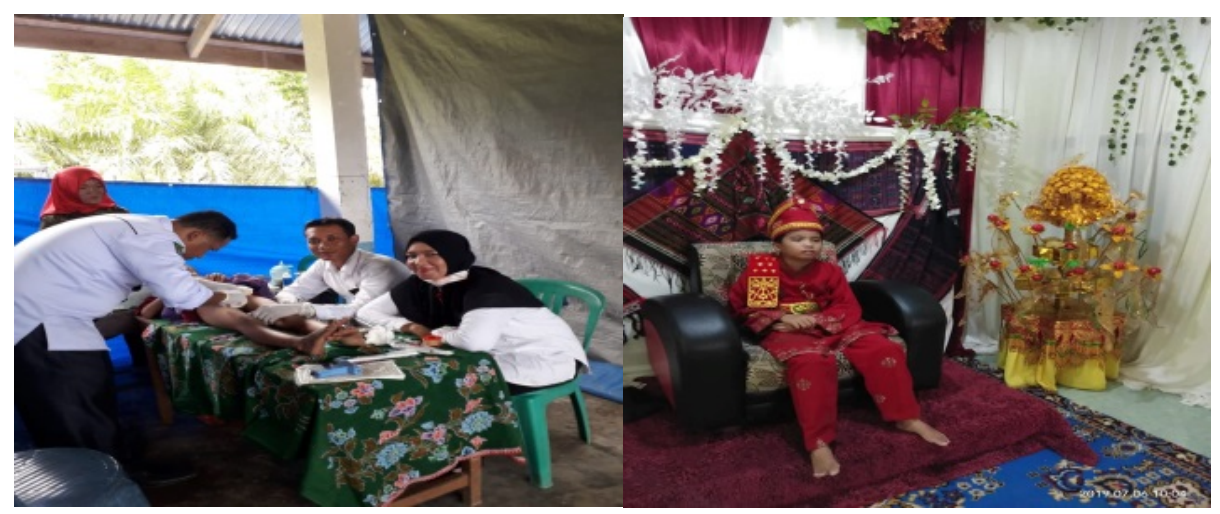

Gambar 2. Tradisi Sunat Rosul

Sumber: Dokumen Penelitian, 2019

\section{- Tradisi Nikah Kawin (Pernikahan)}

Temuan penelitian selanjutnya terdapat nilai-nilai budaya sebagai kearifan lokal masyarakat suku bonai dalam pelaksanaan pernikahan atau Nikah Kawin (Kunduri Godang). Pernikahan bagi masyarakat suku Bonai merupakan suatu kewajiban menjalankan syariat islam. Tradisi nikah kawin bagi masyarakat suku Bonai merupakan hal yang dianggap sakral dalam menempuh hidup, nikah kawin memiliki prosesi adat Bucinok-cinok, Muanta kato, Muanta Tando, Poncak Silek, Ijab Kobul, Malam Buinai, Koba (Bukoba), Upah-upah, Gondang Berogong. Tradisi nikah kawin secara adat dilaksanakan dua hari sampai tiga hari tergantung kesanggupan dari pihak keluarga. Prosesi nikah kawin sering disebut dengan Kunduri Sonik (dua hari) dan Kunduri Godang (tiga hari). Berikut dibawah ini tahapan dari tradisi nikah kawin, sebagai berikut:

$\Rightarrow$ Bucinok-cinok (berkenalan)

Bucinok-cinok dalam bahasa Bonai merupakan proses perkenalan antara lakilaki dan perempuan sebelum melangsungkan lamaran, setelah dikenalkan dan dirasa cocok oleh keduanya maka pihak laki-laki menyampaikan niat baik ini kepada keluarga untuk melamar perempuan tersebut, setelah itu biasanya ditentukan hari untuk muanta kato oleh pihak laki-laki dan mendapat persetujuan dari pihak perempuan. Dimulai dengan makan sirih yang dibawa oleh keluarga laki-laki. Tepak sirih yang dipakai untuk acara ini disebut tepak sirieh tanyu setelah semua yang hadir duduk, tepak diedarkan berkeliling. Kemudian orang sumondo perempuan menanyakan maksud kedatangan rombongan keluarga laki-laki, yang kemudian dijawab oleh orang sumondo laki-laki. Orang sumondo perempuan kemudian menyarankan agar bertanya kepada datuk adatnya. Datuk adat pun menyarankan agar bertanya kepada sanak saudara, orang sumondo dan terutama kepada ponggalang pintu, sebutan untuk anak laki-laki mamak (abang ibu perempuan). Karena, menurut adat 
ialah yang paling berhak mendapatkan sigadis. Setelah semua memberikan persetujuannya, orang sumondo perempuan menyampaikan kepada datuk adatnya. Datuk adat pun menyuruh orang sumondo laki-laki kemudian menyuruh orang sumondo laki-laki untuk menanyakan syarat loka kacuo baruih yang akan diberikan ketika muanta tando. Orang sumondo perempuan akan memberitahukan persyaratan loka kaco baruih (istilah 'tanda' dalam prosesi mengantar kata).

$\Rightarrow$ Muanta Tando

Prosesi muanta tando pada kesempatan ini kedua belah pihak merundingkan hari nikah kawin (pernikahan) dalam menentukan hari dari pihak laki-laki memberikan usulan yang kemudian dipertimbangkan oleh pihak perempuan. Besar-kecilnya kenduri juga diusulkan oleh pihak laki-laki. Menurut adat ada dua tingkatan kenduri yang diusulkan oleh pihak perempuan, yaitu: 1) Kunduri Bosa (berhelat besar), 2) Sodokah sonik (sedekah kecil). Selanjutnya dilaksanakan muanta tando. Apabila hari dan besar-kecilnya barolek sudah disepakati perundingan dilanjutkan dengan membentuk panitia kerja yang ketua panitia dan seksi-seksinya orang sumondo (Keluarga). Hasil perundingan ini dilaporkan kepada datuk adat. Selanjutnya, Datuk adat melalui orang sumondo menyerahkan kerja tersebut kepada ketua panitia.

$\Rightarrow$ Ijab Kobul

Ijab Kobul (Ijab Kabul) merupakan prosesi mengikat janji suci membentuk keluarga yang didampingi penghulu KUA dan dihadiri oleh kedua saksi sebagai bentuk Sah atau resminya mempelai pria dan wanita menjadi suami istri. Mayoritas dari sepasang calon pengantin yang ingin melangsungkan pernikahan melaksanakan ijab kobul di rumah pihak calon mempelai wanita, jikapun tidak, mereka melangsungkan ijab kobul di Kantor Urusan Agama (KUA). Prosesi ijab kobul ini dihadiri oleh Datuk Bendaro dan pemangkupemangku adat lainya sebagai saksi pernikahan. Jika Datuk bendaro tidak bisa datang karena berhalangan, Datuk bendaro harus diwakilkan oleh Tungkek ataupun orang kepercayaannya. Jika proses pengesahan pernikahan dilangsungkan di rumah calon pengantin wanita, maka wali dari KUA harus dibawa kerumah salah satu syarat lainnya agar ijab kobul dapat dilaksanakan adalah adanya mahar (mas kawin) pernikahan.

$\Rightarrow$ Malam Buinai

Malam Buinai dilaksanakan pada malam hari secara bersama oleh pihak keluarga. Perlengkapan berinai dipersiapkan pada siang harinya oleh perempuan-perempuan kerabat dan kawan karib pengantin. Daun inai yang sudah ditumbuk halus dibalutkan pada wadah yang dihiasi rangkaian bunga dan dedaunan asli ataupun bunga dan dedaunan kertas beraneka warna. Acara berinai diawali dengan duduknya pasangan pengantin di atas tilam berhias yang ditempatkan di depan pelaminan. Setelah dibuka oleh pembawa acara, salah seorang jemputan dipersilahkan untuk memulai mendendangkan syair (Barzanji). Setelah acara berinai selesai, makanan ringan dihidangkan. Setelah 
itu, sebagian besar hadirin pindah ke halaman tempat memasak. Di kawasan ini orang-orang bekerja mempersiapkan jamuan untuk pucak kunduri godang, sambil mendengarkan cerita Bukoba yang didendangkan tukang koba.

$\Rightarrow$ Bukoba

Bukoba (Koba) dilaksanakan pada malam hari dengan nyanyian yang didendangkan oleh penyair disebut sebagai tukang koba. Koba dapat ditampilkan baik oleh laki-laki maupun perempuan. Ketika koba dimulai dalam acara nikah kawin masyarakat banyak yang melihat pertunjukan koba yang diiringi dengan alat musik babano (alat musik pukul yang terbuat dari banie pangkal batang kayu). Cerita koba berisikan tentang alam, manusia, hewan, dewa, pantun-pantun, ungkapan dan cerita lainnya. Bila satu malam cerita yang disajikan belum tamat, maka koba dilanjutkan pada malam berikutnya. Menjelang koba disajikan, tukang koba biasanya makan sirih bersama-sama khalayak. Kemudian ia mendendangkan sejumlah pantun dan menyampaikan terima kasih kepada khalayak yang hadir. Tradisi koba memiliki nilai religius dalam sopan santun dalam setiap kalimat di ucapkan, nilai kepedulian dan nilai ketangguhan. Serta syarat akan nilai-nilai budaya sebagai jati diri, nilai-nilai kehidupan dan nilai-nilai luhur yang harus dikembangkan oleh masyarakat suku Bonai di Ulak Patian. Seperti yang diceritakan oleh Pak Yusmar tentang bukoba mengatakan;

“...Biasanya menjelang koba disajikan, tukang koba biasanya makan sirih bersama masyarakat suku Bonai, bahan-bahan makan sirih meliputi pinang, kapur, gambir dan cengkeh. Kemudian tukang koba mendendangkan sejumlah pantun dan menyampaikan terima kasih kepada khalayak yang hadir. Walaupun sekarang ini pelestariannya tidak berjalan dengan baik, karena para generasi muda kurang berminat mempelajari ataupun melestarikan tradisi tersebut, sehingga hanya beberapa orang lanjut usia saja yang masih memainkannya ketika diminta dalam setiap acara masyarakat." (Yusmar, 51 Tahun).

$\Rightarrow$ Upah - Upah

tradisi upah-upah merupakan upacara syukuran pada kedua mempelai. Secara tradisional perlengkapan upah - upah yang harus disiapkan yaitu: nasi kunyit bopangkat (nasi kunyit yang dibuat bertingkat), ada yang bopangkat satu, bopangkat dua sampai bopangkat tiga; panggang ayam yang diletakkan di atas nasi kunyit; kemenyan untuk dibakar diperasapan; beras kunyit dan botieh (bertih) untuk diasapkan dengan kemenyan. Setelah semua disiapkan dalam prosesinya kepala suku maupun orang yang dituakan mengangkat nasi kunyit bopangkat satu tersebut keatas kepala kedua mempelai dengan dibacakan mantera-mantera maupun doa-doa. Umumnya tradisi Upah-Upah ini dilaksanakan di setiap tradisi masyarakat suku Bonai yang meliputi Tradisi Nikah Kawin, Cukuo Rambuik, Sunat Rosul, dan Kegiatan yang sifatnya memberi semangat bagi yang terkena musibah kecelakaan.

$\Rightarrow$ Makan Bukoca

Makan Bokoca merupakan makan bersama-sama setelah prosesi adat dilakukan, makan bersama ini sebagai ucapan terimakasih atas bantuan masyarakat dalam 
mensukseskan tradisi Nikah Kawin. Makan bukoca biasanya diiringi musik tradisional yakni gondang borogong (gendang gong), yang memakai satu set celempong (enam buah celempong), dua buah gendang serta tarian-tarian yang dimainkan oleh beberapa orang dengan sangat merdu didengar tentunya mengeluarkan irama klasik. Serta musik orgen tungga (Keyboard) dari daerah lain yang dibawa oleh pihak mempelai.
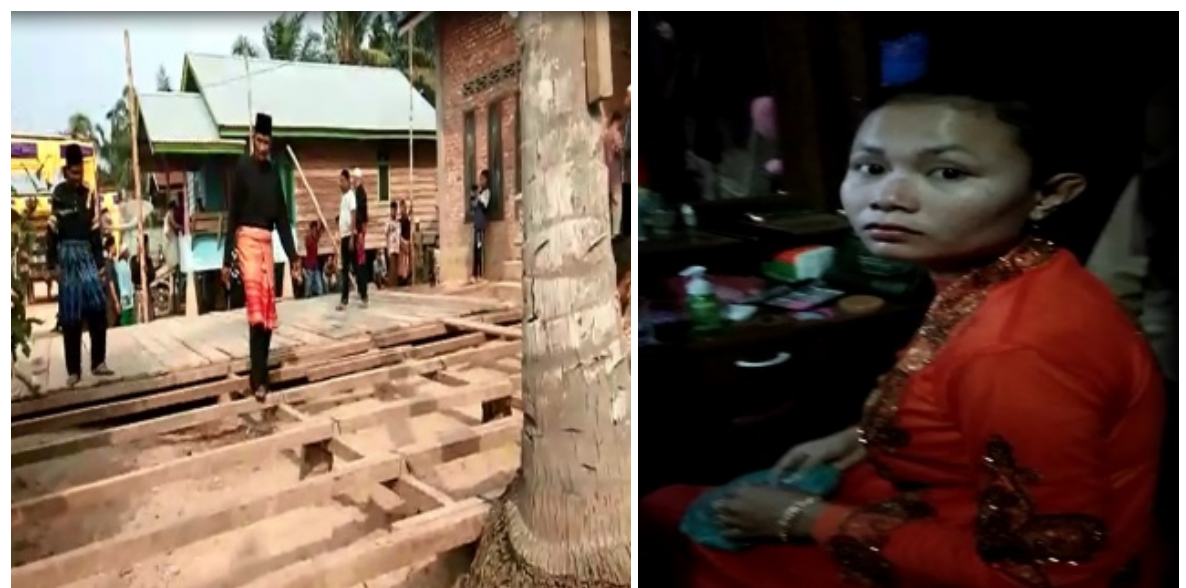

Gambar 3. Tradisi Nikah Kawin

Sumber: Dokumen Penelitian, 2019

\section{- Tradisi pocak silek (pencak silat)}

Temuan penelitian selanjutnya terdapat dalam tradisi pencak silat (Poncak Silek) Poncak silek merupakan bentuk seni bela diri masyarakat suku Bonai yang tingkatan paling tinggi dan halus. Poncak silek tidak memiliki kesan kekerasan dalam gerakan pada pertunjukannya melainkan tarian hiburan yang mengandung nilai kesopanan, kehalusan budi, dan penghormatan terhadap lawan tandingnya. Tarian Poncak silek ini memiliki nilai estetika (keindahan) dalam setiap gerakan dengan aturan-aturan tertentu yang dipelajari oleh penari silek. Aturan-aturan tersebut dikenal dengan adab dalam Poncak silek suku Bonai, adab yang ditunjukan sebelum bertarung berupa sikap dan kata-kata. Dalam aturan tersebut ada tingkatannya sebagai adab, yaitu tido bulih munyorang (tidak boleh menyerang dahulu), mengelak (Menghindar) dan menangkih (Menangkis) Serangan lawan. Ketika datag (datang) serangan lawan mengancam jiwa dengan senjata tajap (tajam), maka pendekar berhak untuk menikam lawannya. Dahulu pemuda suku Bonai di Ulak Patian dianjurkan untuk berlatih silek, karena silek mengandung ilmu kebatinan dengan tujuan agar membekali diri pemuda suku Bonai yang pergi merantau serta dapat meneruskan silek dan ilmu kebatinan yang dimilikinya. Orang yang sedang belajar silat disebut monuntuik (mempelajari) silek biasanya murid mengambil silek gerak terlebih dulu, setelah mahir dalam silek gerak barulah dilanjutkan dengan moambiek batin (mempelajari silat batin). Pada dasarnya azas silek gerak dalam Poncak Silek suku Bonai di Ulak Patian sama dengan aliran silak yang lain, tetapi berbeda nama dan cara mengajarnya yang bersifat sebagai pelengkap dan tambahan dalam Poncak silek yang ada di Rokan Hulu. Seperti yang dijelaskan oleh M. Yunus tentang poncak silek suku Bonai mengatakan; 


\begin{abstract}
"Poncak silek semata-mata berupa tarian yang indah dengan aturan-aturan tertentu yang harus dipelajari oleh seorang penari silek, sehingga tidak semua pesilat bisa menarikan tarian poncak silek tersebut sebelum ia belajar aturan dan cara-caranya. Poncak silek suku Bonai satu-satunya tarian yang hidup dan berkembang dalam masyarakat bonai hingga sekarang. Tarian ini digunakan dalam berbagai acara, seperti penyambutan tamu, kenduri adat, perayaanperayaan dalam negeri atau dalam kampung, kenduri pernikahan atau khinatan. Adakalanya seseorang hanya belajar tarian silat saja dan tidak ikut serta dalam gelanggang atau kaji batin. Pencak silat ditampilkan dengan iringi musik gondang borogong (gendang gong), yang memakai satu set celempong (enam buah celempong), dua buah gendang. Dalam Poncak silek gelanggang berbentuk segi empat dan dipasang pagar kayu yang rapat ditancapkan setiap sudut merupakan tempat untuk berlatih gerak silek yang terletak di tepi kampong Ulak Patian." (M. Yunus, 30 Tahun).
\end{abstract}

Poncak Silek merupakan identitas yang berciri khas masyarakat suku Bonai di Ulak Patian, melalui seni beladiri Poncak Silek ini sebagai pertahanan diri anak kemenakan masyarakat suku Bonai ketika melawan musuh, bukan untuk membanggakan diri dan kesombongan. Poncak silek masyarakat suku Bonai mengutamakan kepribadian yang memiliki jiwa bersih atau bersyariatkan nilai agama islam sebagai pondasi dalam Poncak Silek yang ditandai dalam gerakan silek menghormati lawannya. Sejalan pendapat Kumaidah bahwa pencak silat sebagai aspek mental-spiritual, pencak silat lebih banyak menitik beratkan pada pembentukan sikap dan watak kepribadian pesilat yang sesuai dengan falsafah budi pekerti luhur. (Kumaidah, E., 2012). Seperti yang diungkapkan dari penelitian de Castella, (2006) menunjukkan bahwa silat dapat membangun harga diri, mengajarkan bagaimana menangani oposisi dan agresi. Banyak anak-anak tidak pernah melihat seseorang yang kuat secara fisik yang memilih untuk tidak menggunakannya dengan cara kekerasan. (Syan, M \& Hamdat, S., 2019). Maka setiap gerakkan dari Poncak Silek mengandung nilai-nilai kehalusan budi, kesopanan, menghormati dan menghargai sebagai adab pesilek (pesilat) suku Bonai yang diambil dari aktivitas interaksi lingkungan sebagai simbol pegangan hidup masyarakat suku Bonai yang memiliki filosofi tinggi dalam membentuk mental, fisik dan spritual. Nilai-nilai inilah yang menjadi wujud dari kebudayaan suku Bonai tercermin dari setiap teknik gerakan menyesuaikan lingkungan sekitar.

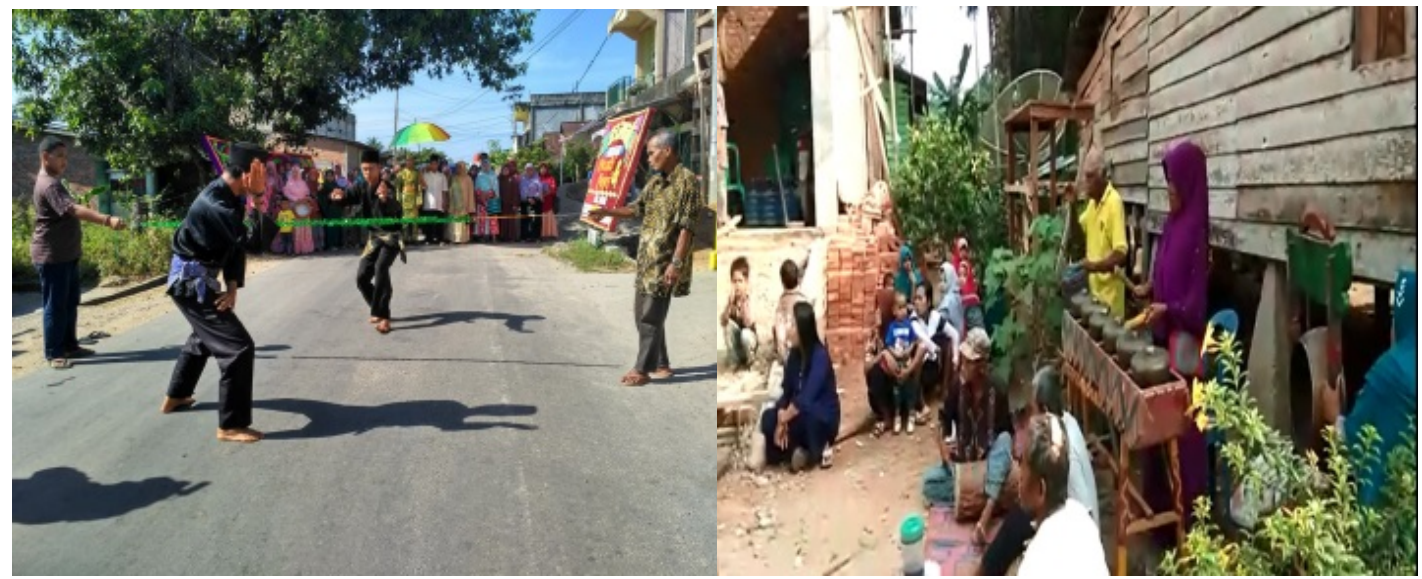

Gambar 4. Poncak Silek Pada Acara Nikah Kawin Sumber: Dokumen Penelitian, 2019 


\section{- Tradisi dalam tarian cegak dan tarian buwong kuayang}

Temuan penelitian terdapat dalam kesenian tradisional masyarakat suku Bonai yang sudah ada sejak dahulu, meliputi Tarian Cegak dan Tarian Buwong Kuayang yang merupakan seni pertunjukan bagi masyarakat suku bonai di Desa Ulak Patian, seni pertunjukan inilah menjadi simbol kebudayaan suku Bonai. Tarian tersebut masih dijumpai aktivitasnya sampai saat ini. Karena bagi masyarakat suku Bonai kesenian dipadang sebagai spirit dalam siklus kehidupannya, terdapat unsur-unsur tradisi yang menghiasi setiap gerakkan tarian tersebut. Tarian Cegak menurut bahasa bonai memiliki dua arti, pertama samar-samar dan kedua sembuh kembali. Sebagai tarian penutupan dalam tradisi nikah kawin yang diawali dengan kisah pada zaman penjajahan belanda, muncul perlawanan dari masyarakat bonai yang bergabung dengan para pejuang melayu. Seperti yang dijelaskan oleh Pemimpin Tari cegak M. Rasyid tentang sejarah Tarian Cegak mengatakan;

"...Ketika itu lima pemuda bonai terlibat melawan belanda, dan mereka menuntut ilmu salin rupa, yakni kemampuan menghilangkan dari pandangan manusia. Singkatnya cerita ilmu salin rupa itu langsung dipakai seketika itu juga. Berubahlah mereka menjadi krisiek pisang. Sehingga sudah tidak terlihat lagi oleh opas belanda yang mencari itu. Ketika keadaan sudah aman, mereka bingung bagaimana merubah wujud seperti semula. Selama lima belas hari dilalui namun tubuh mereka tetap dibalut oleh kerisiek pisang. Masuk hari kelima belas sayup-sayup terdengar suara kenduri dimeriahkan dengan gondang berogong. Kelima sepakat menjenguk tempat kenduri itu, dan menyaksikan gondang borogong dari balik semak-semak. Kelima pemuda itu kemudia menari mengikuti irama gondang borogong. Pada saat 60usic berhenti, tak disangka mereka berubah kembali normal, tak lagi terlihat mengenakan krisiek pisang dan akhirnya mereka sembuh atau cegak dengan sendirinya apabila telah genap lima belas hari." (M. Rasyid, 60 Tahun).

Tarian cegak merupakan seni pertunjukan warisan budaya masyarakat suku Bonai di Ulak Patian. Walaupun dulunya tarian ini sebagai sarana hiburan bagi masyarat suku Bonai setelah letih bekerja. Tarian cegak ini menggunakan mantera sebelum pertunjukan dimulai, agar roh-roh nenek moyang mereka hadir dalam menjaga dan memberi kekuatan bagi mereka dalam menampilkan seni pertunjukannya. Selanjutnya dijelaskan pak Zainuddin mengatakan;

“.... Dulu tarian cegak selalu menggunakan mantera-mantera untuk memanggil roh nenek moyangnya dalam setiap penampilan, tetapi setelah masyarakat suku Bonai mengenal agama islam melalui Thareqat Naqsabandi yang dibawa suku Melayu mereka melarang mantera dijadikan awal pembuka tarian dan digantikan dengan do'a pada awal pembuka tarian cegak. Perlengkapan dalam menampilkan tarian cegak ini menggunakan pakaian dari kulit kayu, gondang, dan diiringi oleh dondayang memainkan musik gondang borogong." (Zainuddin, 38 Tahun).

Sedangkan, seni pertunjukan Tarian Buwong Kuayang merupakan tarian dalam upacara ritual dewo yang menjadi upacara pengobatan bagi masyarakat suku Bonai yang selama ini dilaksanakan ketika ada salah satu masyarakatnya yang sakit sehingga mereka mengobatinya dengan ritual dewo yang dilakukan oleh kemantan. Ritual dewo terdapat sebuah seni pertunjukan murni yang di dalamnya ada tarian pengobatan (tari buwong kuayang) yang dilaksanakan dalam acara 
pernikahan dan acara besar lainnya. Selanjutnya dijelaskan oleh pak Sahril tentang Ritual Dewo mengatakan;

"Prosesi ritual dewo pertama yang dilakukan pemantan meletakkan balai mukun dengan kelongkap (perlengkapan) seperti botih, bunga warna putih, moyang pinang, tanak pinang, penganyaman ditengah halaman. Setelah itu pemantan duduk buselo (bersila) menghadap balai mukun di depan pasien yang sudah dibaringkan serta para dondayang (dayang-dayang) dan dubalang duduk disamping kiri dan kanan balai mukun setelah itu pemantan membakar kemenyan serta menghisap perasapan sambil membaca mantera yang bertujuan untuk memasuki alam roh. Ketika pemanggilan roh dewo berlangsung, dan turun ke balai mukun untuk mengobati pasien, maka pemantan mendendangkan lagu-lagu roh dewo sambil menari-nari bersama dubalang di iringi gondang senungko dan sampai akhirnya selesai pengobatan." (Sahril, 55 Tahun).

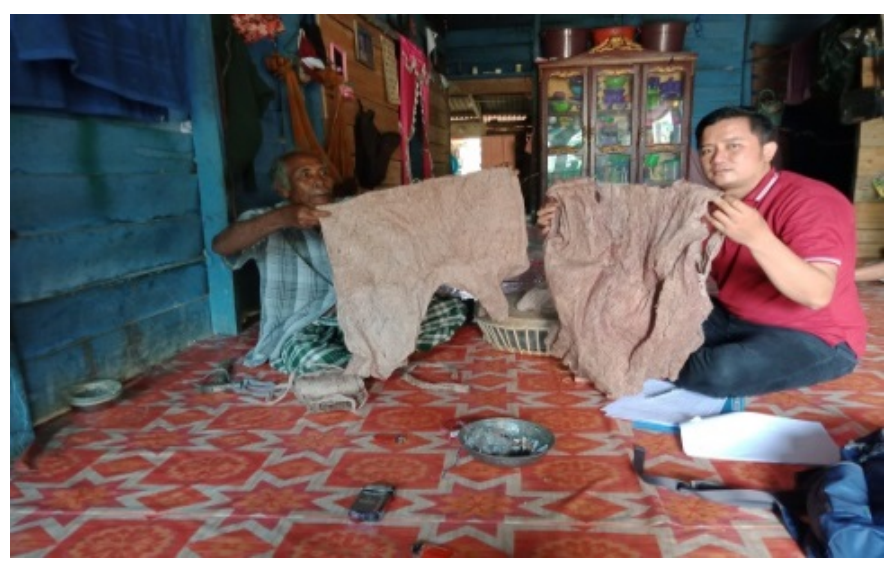

Gambar 5. Pakaian Tarian Cegak dan Buwong Kuayang Sumber: Dokumentasi Penelitian, 2019

Tradisi Suku Bonai melalui seni pertunjukan mendapat apresiasi dari pemerintah kabupaten Rokan Hulu yang merupakan warisan budaya yang harus dilestarikan. Seperti dijelaskan oleh Gustia Hendri mengatakan;

“Apresiasi Pemerintah kabupaten Rokan Hulu melalu Dinas Pariwisata dan Kebudaya dalam pelestarian tarian tersebut sudah ditampilkan dalam acara join performance art Indonesia-Singapore tahun 2011, pada acara stasiun televisi Trans 7 Jejak Petualang 2014, MTMA 2017, Parade Kebudayaan di TMII tahun 2017, Pawai ta'aruf MTQ Provinsi Riau tahun 2017 di kota Dumai, Festival budaya Melayu Riau di Taman Budaya Provinsi Riau Tahun 2019 dan ditetapkan tari Cegak dan Buwong Kuayang dari Menteri Pendidikan dan Kebudayaan Republik Indonesia sebagai Warisan Budaya Tak Benda (WBTB) tahun 2019." (Gustia Hendri, 34 Tahun).

Kesenian tradisional suku Bonai yang menjadi indentitas masyarakat suku Bonai itu diwariskan secara turun temurun yang mengandung nilai estetika dan nilai religius dalam setiap gerakannya yang timbul dari apa yang dirasakannya. Seperti pendapat Sendjaja (1982) bahwa kesenian tradisional merupakan hasil karya, cipta dan karsa manusia yang bersumber dari aspek perasaan, yaitu perasaan estetis yang bersifat lokal dalam arti digemari oleh kelompok masyarakat tertentu dan juga lahir dari kelompok tersebut. Menurut Kosim bahwa cita rasa dalam kesenian tradisional mempunyai pengertian yang luas, termasuk nilai kehidupan tradisi, pandangan hidup, pendekatan filsafah, rasa etis dan estetis, serta ungkapan budaya 
lingkungan, hasil kesenian tradisional biasanya diterima sebagai tradisi pewarisan yang dilimpahkan dari angkatan tua ke angkatan muda (Yoeti, 1985). Maka, kesenian tradisional suku Bonai di Ulak Patian sudah mengalami perubahan dari segi fungsi, makna dan bentuk penyajiannya sudah mengandung nilai agama dengan lantunan ayat suci al-quran tanpa menggunakan mantera-mantera dalam awal pembuka kesenian tersebut. Ini membuktikan bahwa kesenian tradisional masyarakat suku Bonai tetap diterima masyarakat walaupun meninggalkan nilai magisnya sebagai bentuk ketaatan kepada Allah Swt. Dengan kata lain tidak merubah esensi nilai estetika dari Tradisi Cegak dan Buwong Kuayang tersebut. Tetapi tarian tersebut menjadi salah satu bentuk eksistensi suku Bonai, dipandang sebagai perhelatan yang tinggi adatnya bagi masyarakat dan sebagai simbol kebanggaan Desa Ulak Patian serta Kabupaten Rokan Hulu. Sehingga Kesenian tradisional dalam tarian cegak dan buwong kuayang menjadi warisan budaya tak benda (WBTB) dari Kementrian Pendidikan dan Kebudayaan pada tahun 2019.

\section{- Tradisi lukah gilo dan tahan kulik}

Lukah Gilo dan Tahan Kulik merupakan tradisi kesenian yang ditampilkan dalam pertunjukan masyarakat suku Bonai di Ulak Patian. Tradisi tarian Lukah Gilo terdapat perpaduan dari gerak dan ilmu kebatinan yang dimainkan pada acaraacara tertentu yang sifatnya ritual. Lukah dipegang bersama-sama, sambil membacakan mantra-mantra oleh salah satu dari mereka sampai terasa lukah itu bergerak dengan sendirinya dengan sangat kuat hingga waktu ditentukan oleh batin. Seperti yang diceritakan oleh M. Midun tentang Lukah Gilo mengatakan;

“... lukah gilo merupakan tarian dalam bentuk permainan adat tradisional masyarakat suku Bonai di Ulak Patian, tarian ini dimainkan oleh beberapa orang dengan menggunakan pakaian terbuat dari kulit kayu atau pakaian lainnya. Lukah (Keranjang Ikan) biasanya dihiasi dengan kain yang menyerupai orangorangan, setelah itu pada prosesinya lukah tersebut dipegang beberapa orang dan dibacakan mantera-mantera oleh pemimpinnya dengan tabuhan gendang. Setelah dibacakan matera maka lukah tersebut bergerak sendiri ke kiri dan ke kanan oleh bantuan tenaga gaib yang di undang melalui matera-mantera. Tradisi ini juga masih dilestarikan oleh masyarakat suku Bonai yang ditampilkan pada acaraacara besar seperti memperingati hari jadi Desa Ulak Patian, Kecamatan dan Kabupaten Rokan Hulu." (M. Midun, 30 Tahun).

Sedangkan Tahan Kulik dalam tradisi tarian suku Bonai yang memiliki perpaduan antara gerakkan dan ilmu kebatinan yang dimilikinya. Peralatan yang digunakan dalam tarian ini biasanya mengunakan pisau atau parang, pakaian juga dari kulit kayu dan Krisiek Pisang. Kesenian tahan kulik juga ditampilkan dalam acara-acara besar seperti upacara adat dan sebagainya. Dalam permaian tersebut batin mengambil sebuah parang dan melakukan gerakan tarian serta memakai parang tersebut lalu dipukul dan digoreskan keseluruh anggota tubuh batin yang tidak mengeluarkan darah sama sekali atau kebal terhadap benda tajam. Selanjutnya dijelaskan oleh Amrizal mengatakan;

"Permainan tradisional dalam tahan kulik ini merupakan penyaluran ilmu kebatinan yang di pelajari melalui pocak silek dari amalan silek duo puluh satu hari dan silek bangkik, bagi mereka yang dinyatakan berhasil melewati silek tersebut bisa memainkan pertunjukan tahan kulik. Masyarakat suku Bonai 
meyakini tahan kulik sebagai simbol ketangguhan atau kekuatan bagi mereka yang hendak merantau ke daerah lain. Prosesi dalam pertujukan tahan kulik ini tidak jauh beda dengan luka gilo menggunakan mantera atau do'a supaya mendapat kekuatan magis pertahanan diri. Selanjutnya batin tersebut mengambil sebuah parang dengan menggoreskan keseluruh tubuh tanpa melukai badan batin tersebut." (Amrizal, 38 Tahun).

Dalam kaitan kearifan lokal untuk mengetahui apakah nilai-nilai budaya yang terdapat dalam masyarakat suku Bonai sebagai Kearifan Lokal. Menurut Gobyah (Sartini, 2004) yang menyatakan bahwa "kearifan lokal (lokal genius) adalah kebenaran yang telah mentradisi atau ajeg dalam suatu daerah. Masyarakat pada dasarnya tidak dapat dilepaskan dari nilai-nilai tradisi dan budaya yang turun dari generasi satu ke generasi seterusnya. Menurut Geertz, 2007, (dalam Ernawi, 2010) dikatakan bahwa:'...kearifan lokal merupakan identitas yang sangat menentukan harkat dan martabat manusia dalam komunitasnya'. Oleh karena itu manakala nilai-nilai tradisi dan budaya pada masyarakat tercabut dari akar budayanya, maka masyarakat akan kehilangan identitas dan jati dirinya. Sesuai pendapat Handayani, D (2012) bahwa masyarakat suku Bonai merupakan masyarakat asli yang masih memegang teguh tradisi dan budayanya. Walaupun masyarakat suku Bonai telah memeluk agama islam, masyarakat suku Bonai masih menjaga dan memperlihatkan kuatnya aturan hukum adat, budaya, dan tradisi, demi memperlihatkan identitas sosial mereka.

Berdasarkan hasil penelitian dan pembahasan di atas, dapat dikatakan bahwa kebiasaan yang dilakukan dalam masyarakat suku Bonai yang sudah menjadi sebuah adat-istiadat yang dilaksanakan secara turun menurun warisan nenek moyang, maka kebiasaan yang berupa sikap dan perilaku masyarakat yang mentradisi didasari oleh nilai-nilai yang diyakini kebenaranya ini merupakan wujud dari kearifan lokal. Jadi nilai-nilai budaya sebagai kearifan lokal suku Bonai di Ulak Patian ditandai dengan tradisi dalam kebudayaan masyarakat suku Bonai meliputi: Tradisi Cukuo Rambuik, Sunat Rosul, Nikah Kawin (Kunduri Bosa) yang memiliki prosesi adat Bucinok-cinok, Muanta kato, Muanta Tando, Poncak Silek, Ijab Kobul, Malam Buinai, Koba (Bukoba), Upah-upah, Poncak Silek dan Tradisi dalam Tarian Cegak, Buwong Kuayang, dan permainan tradisional Lukah Gilo serta Tahan Kulik.

Sedangkan dalam proses kebudayaan suku Bonai sebagai nilai-nilai kearifan lokal yang harus dilestarikan menjadi simbol masyarakat desa Ulak Patian untuk meningkatkan eksistensi di dalam kehidupan masyarakat Rokan Hulu dan menjadi jati diri masyarakat suku Bonai yang berupa nilai-nilai budaya meliputi: (1) Nilai Religius: kehalusan budi, keadilan, kebenaran, dan kesopanan yang ditampilkan sebagai penghormatan oleh pemangku adat suku Bonai dalam memimpin upacara ritual meliputi Tradisi Cukuo Rambuik, Sunat Rosul, Kunduri Bosa, Upah-Upah, Poncak Silek, Tarian Cegak, Buwong Kuayang dan Lukah Gilo. Dalam upacara ritual dibacakan doa-doa yang terdapat dalam Alquran. Kegiatan ritual ini bertujuan untuk meminta keselamatan kepada Allah SWT dan mendapat perlindungan dari Allah. (2) Nilai Estetika (keindahan): nilai estetika ini ditampilkan dalam bentuk karya seni baik itu berupa suara, musik, maupun tarian. Dalam tradisi Cukuo Rambuik, Sunat Rosul, Kunduri Bosa, dan Poncak Silek dari 
awal sampai ritual selesai, diiringi oleh musik Gondang Borogong. Serta tradisi tersebut diiringi oleh berbagai tarian seperti Poncak Silek, Tarian Cegak, Buwong Kuayang, Lukah Gilo dan Tahan Kulik. (3) Nilai Kebersamaan: nilai kebersamaan ditampilkan dalam keterlibatan masyarakat dalam Tradisi Cukuo Rambuik, Sunat Rosul, Kunduri Bosa, Upah-Upah, Poncak Silek, Tarian Cegak, Buwong Kuayang dan Lukah Gilo. Dalam tradisi ini budaya gotong royong dan tolong menolong menjadi bagian disetiap awal pelaksanaan tradisi tersebut sampai selesai. (4) Nilai Demokratis: nilai demokratis terlihat dalam persiapan menjelang upacara Tradisi Cukuo Rambuik, Sunat Rosul, Kunduri Bosa, Upah-Upah, Poncak Silek, Tarian Cegak, Buwong Kuayang dan Lukah Gilo. Berbagai aspirasi ditampung dan dimusyawarahkan agar mencapai keputusan secara demokratis dan bertanggung jawab dalam melaksanakan tradisinya.

\section{Kesimpulan}

Berdasarkan hasil penelitian yang diuraikan pada bahasan sebelumnya, maka dapat disimpulkan bahwa masyarakat suku Bonai di Ulak Patian memiliki nilai-nilai budaya sebagai kearifan lokal yang merupakan warisan nenek moyang sejak dahulu, nilai-nilai budaya tersebut tertanam dan dilestarikan oleh anggota masyarakatnya sebagai simbol jati diri suku Bonai yang meliputi Nilai Religius, Nilai Estetika, Nilai Kebersamaan, dan Nilai Demokratis. Peneliti berasumsi bahwa nilai budaya yang terkadung menjadi suatu pedoman menjalankan kehidupan bagi masyarakat suku Bonai mampu menjaga dan memperlihatkan kuatnya aturan hukum adat, budaya, dan tradisi, demi memperlihatkan identitas sosial mereka.

Maka nilai-nilai budaya tersebut sebagai Kearifan Lokal masyarakat suku Bonai yang meliputi: (1) Nilai Religius yang meliputi nilai kehalusan budi, keadilan, kebenaran, dan kesopanan yang ditampilkan sebagai penghormatan oleh pemangku adat suku Bonai dalam memimpin Upacara Ritual Tradisi Cukuo Rambuik, Sunat Rosul, Kunduri Bosa, Upah-Upah, Poncak Silek, Tarian Cegak, Buwong Kuayang dan Lukah Gilo. Dalam upacara ritual dibacakan doa-doa yang terdapat dalam Al-Quran. Kegiatan ritual ini bertujuan untuk meminta keselamatan kepada Allah SWT dan mendapat perlindungan dari Allah. (2) Nilai Estetika (keindahan): nilai estetika ini ditampilkan dalam bentuk karya seni baik itu berupa suara, musik, maupun tarian pada tradisi Cukuo Rambuik, Sunat Rosul, Kunduri Bosa, dari awal sampai ritual selesai, diiringi oleh musik Gondang Borogong. Serta tradisi tersebut diiringi oleh berbagai tarian seperti Poncak Silek, Tarian Cegak, Buwong Kuayang, Lukah Gilo dan Tahan Kulik. (3) Nilai Kebersamaan: nilai kebersamaan ditampilkan dalam keterlibatan masyarakat dalam bergotong royong dan tolong menolong dari awal pelaksanaan sampai akhir dari tradisi tersebut sebagai bentuk aktivitas dalam kebersamaan dan kekeluargaan yang terjalin sejak dulu sampai sekarang, meliputi kegiatan tradisi Cukuo Rambuik, Sunat Rosul, Kunduri Bosa, UpahUpah, Poncak Silek, Tarian Cegak, Buwong Kuayang dan Lukah Gilo. (4) Nilai Demokratis: nilai demokratis terlihat dalam pelaksanaan persiapan Upacara Ritual Tradisi Cukuo Rambuik, Sunat Rosul, Kunduri Bosa, Upah-Upah, Poncak Silek, Tarian Cegak, Buwong Kuayang dan Lukah Gilo. Berbagai aspirasi ditampung dan dimusyawarahkan agar mencapai keputusan secara demokratis dan bertanggungjawab dalam melaksanakan tradisinya. 


\section{Referensi}

Ayatrohaedi. (1986). Keperibadian budaya bangsa (Local Genius). Jakarta: Pustaka Jaya Budimansyah, dkk. (2004). Dinamika Masyarakat Indonesia. Bandung. PT. Genesindo.

Creswell. J.W. (1994). Reserach design qualitative \& quantitative approaches. California: Sage Publications.

Horton, P. B \& Chester L. H. (1996). Sosiologi. Jakarta: Penerbit Erlangga.

Koentjaraningrat. (2009). Pengantar antropologi. Jakarta: PT Rineka Cipta.

Miles \& Huberman. (2007). Analisis data kualitatifbuku sumber tentang metode-motode baru. Jakarta: Universitas Indoneisa Press.

Sendjaja \& Juarsa, S. (1982). Media Kesenian Tradisional, Tinjauan Terhadap kedudukan dan Karakteristik Kesenian Tradisional Sebagai Medium Komunikasi Pembaharuan, Analisis Kebudayaan III, Bandung: Depdikbud.

Yoeti, O. K. (1985). Melestarikan Seni Budaya Yang Nyaris Punah. Jakarta: Depdikbud.

Alus, C. (2014). Peran lembaga adat dalam pelestarian kearifan lokal suku sahu di desa Balisoan kecamatan Sahu Kabupaten Halmahera Barat. Jurnal Acta Diurna. Vol. 3, No. 4, hlm. 1-16.

Ellya, R. (2017). Dinamisasi Kebudayaan dalam Realitas Sosial. Jurnal Al-Adyan: Jurnal Studi Lintas Agama. Vol.12, No.1, hlm. 16-30.

Ernawi, S. M. (2010). Harmonisasi Kearifan Lokal Dalam Regulasi Penataan Ruang, (Online), Makalah Pada Seminar Nasional 'Urban Culture, Urban Future, Harmonisasi Penataan Ruang dan Budaya Untuk Mengoptimalkan Potensi Kota, Pada http:/ / www.penataanruang.net, (5 November 2019).

Fajarini, U. (2014). Peranan kearifan lokal dalam pendidikan karakter. Universitas Islam Negeri Syarif Hidayatullah. Jurnal Sosio Didaktika. Vol. 1, No. 2, pp. 123-130.

Handayani, D. (2012). Tradisi Ritual Lukah Gilo Pada Masyarakat Suku Bonai Provinsi Riau. Tesis. Universitas Sumatera Utara.

Islamuddin. (2014). Pengembangan Budaya Suku Talang Mamak Sebagai Nilai-Nilai Kearifan Lokal Dalam Bagian Civic Culture (Studi Etnografi Pada Masyarakat Suku Talang Mamak Di Kecamatan Rakit Kulim, Kabupaten Indragiri Hulu, Propinsi Riau). Jurnal Pendidikan Ilmu Sosial. Vol 23, No. 2, hlm. 55-67.

Kumaidah, E. (2012). Penguatan Eksistensi Bangsa Melalui Seni Bela Diri Tradisional Pencak Silat. Jurnal Kajian Ilmiah Humaniora. Vol 16, No. 9, hlm. 1-9.

Prayogi, R., Danial, E. (2016). Pergeseran nilai-nilai budaya pada suku Bonai sebagai civic culture di Kecamatan Bonai Darussalam. Kabupaten Rokan Hulu. Provinsi Riau. Jurnal Humanika. Vol 23. No. 1, hlm. 61-79.

Sartini, (2004). Menggali Kearifan Lokal Nusantara Sebuah Kajian Filsafati (Jurnal Filsafat). Jakarta: Universitas Gadjah Mada. Vol. 14, No. 2, hlm. 111-120.

Syan, M., Hamdat, S. (2019). Manca': Kajian Tentang Simbol Seni Beladiri Sebagai Identitas Budaya Makassar di Gowa Sulawesi Selatan. ETNOSIA: Jurnal Etnografi Indonesia. Vol 4. No. 2, hlm. 193-206.

Yance, I. (2018). Penggunaan Bahasa dan identitas Suku Bonai. Jurnal Metalingua. Vol 16. No. 2, hlm. 221-229. 